\title{
Quantum Aspects in Text Perception
}

\author{
Gulfiya Zh. Kuchumova \\ MA, senior teacher, Kazakh University of Humanities and Law, Astana, Kazakhstan \\ ngulfiya2010@mail.ru \\ Aknur M. Toleubayeva \\ MA, senior teacher, Kazakh University of Humanities and Law, Astana, Kazakhstan \\ aknur.87@mail.ru \\ Zhainagul S. Beisenova \\ Prof. Dr. Philological Sciences, Kazakh University of Humanities and Law, Astana
}

\section{Doi:10.5901/mjss.2014.v5n4p573}

\begin{abstract}
Text is difficult to study because it is a psychological phenomenon, one that intimately associated with other aspects of psychological structure. That is, the purpose of this article is to shed some light on the nature and structure of text taking into consideration recent achievements of cognitive science, information theory and quantum linguistics. Consequently, the given paper attempts to present as clearly and simply as possible the fundamental insights about titles of literary texts because the study of titles might provide the key to understanding the author's intention encoded in text. In this paper we shall explore some properties of the text perception aiming at deciphering the author's intention. In particular, we intend to examine the cognitive nature of two kinds of relations named prospection and retrospection between such compulsory components of any text (the possibility of exceptions is not excluded) as its title and body. The research carried out with the help of such methods as linguistic analysis, contextual analysis, perceptive analysis, and method of quantification resulted in conclusion that title of text plays a significant role in text perception and interpretation processes performing the function of 'a generator' that facilitates text quantification process. Due to text title the reader concentrates on key words, expressions, images carrying meaningful information for text understanding. The given findings can be certainly employed in creation of computer programs aimed at automatic deciphering core information in texts or literary text translation practice.
\end{abstract}

Keywords: text perception, quanta, quantum linguistics, prospection, retrospection.

\section{Introduction}

The work done by translators is challenging and stressful as it is evident from practice because translating is considered as one of the intellectual processes demanding perfect language awareness, well-developed translating skills, background. Translation of literary works, such as novels, stories, poetry, etc. is twice challenging as the nature of texts in question defines translation techniques used by translators to render images, emotions in the most appropriate way. One of the keys to successfully convey a literary text from one language into another one is connected with the correct, adequate interpretation of text to be translated. On the basis of this understanding a great attention in training future translators and interpreters is paid to teaching students to analyze texts.

Working out our own course in text interpretation we have defined a new approach to interpreting titles of literary texts employing principles of cognitive and quantitative linguistics. The given approach is assumed to facilitate the process of text analysis by decreasing the time spent on text interpretation as the source text reader focuses mostly on information, associations connected with title.

Text is created to be read and understood, because it is considered as a certain kind of message sent to the reader by the writer. Text is a unique speech act with its own peculiarities and properties one of which is its communicative intention encoded by the sender with the help of discrete language units. Consequently, text is a piece of information that the receiver obtains due to verbal signs scrupulously selected and combined by the sender to transmit his thoughts, beliefs, attitudes, feelings, and emotions. Thus, text is understood as a part of the information transmission system author - text - reader that is mainly based on information theory developed by Claude E. Shannon who mostly dealt with the problem of fundamental limits on compressing and reliably storing and communicating data.

Today information theory is defined as a branch of applied mathematics and electrical engineering involving the quantification of information. Since its inception information theory has broadened to find applications in many other 
areas, for example natural language processing. Moreover, the results of information theory that later were thoroughly presented in quantum theory are widely used in contemporary language analyses belonging to the field of a new branch of language study called quantum linguistics. According to the data provided by quantum linguistics language recognition is assumed as a dynamic process based on the idea that information is absorbed in quantities or quanta [1]. The implication here is that text perception can also be of the same nature as language recognition. The given working hypothesis suggests that in order to amplify the essence of text perception it is vital to define the notion 'quantum' in linguistic terms.

The word quantum is Latin for 'how great' or 'how much'. In quantum mechanics, it refers to a discrete unit that quantum theory assigns to certain physical quantities. In linguistics, quantum is understood as a discrete language unit possessing meaning necessary to decode a message. Similar kinds of characteristics are observed in text quantum that is determined in the given paper as a discrete unit of any subsystems of language structure (phonological, semantic, syntactic) presented in the text and characterized by deep meaning essential for text perception.

We turn now to an examination of the phenomenon known as text perception. In philosophy, psychology, and the cognitive sciences, perception is the process of attaining awareness or understanding of sensory information. The word 'perception' comes from the Latin words perceptio, percipio, and means 'receiving, collecting, action of taking possession, apprehension with the mind or senses' [2, p.57]. What one perceives is a result of interplays between past experiences, including one's culture, and the interpretation of the perceived. This fact is true for text perception as well because it belongs to active perception that can be surmised as dynamic relationship between description (in the brain) - senses surrounding, all of which holds true to the linear concept of experience. Furthermore, cognitive theories of perception assume there is a poverty of stimulus. This is the claim that sensations are, by themselves, unable to provide a unique description of the world. 'Sensations require 'enriching', which is the role of the mental model' [3, p.128]. In other words, as it is viewed by us, 'enriching' of sensations depends upon linguistic and extra-linguistic knowledge of the reader.

A conclusion to be drawn from the above-mentioned ideas is that quanta intuitively found in the text (Heisenberg's uncertainty principle) are perceived, firstly, as sensations because they are explicitly (graphically: exclamation mark, dash, inverted commas, register, etc.) or implicitly (indirect meaning, metaphor, intertextuality, etc.) marked in the text and in this way appeal to the reader's perception ability. A bit later, almost simultaneously, accepted sensations are turned into images, later, into meanings, and only then into sense that is the last stage of the text comprehension process. Needless to say, that the reader does not always succeed in achieving the last text perception stage as it is greatly determined by his private experience that is known as thesaurus. In addition, the made assumption is provided by one of the remarkable functional properties of quantum phenomena that is non-determinism. It is natural to speculate that this property may play an important role in the explanation of cognitive functions, such as random choice and the integration of information taking place at stages of text perception described above.

However, the principle of non-determinism governing text perception does not mean that the text is devoid of concrete sense. Such understanding can make us run to extremes and think pessimistically that text linguistics is not worth further development. That is why, after a detailed analysis of texts, their nature, structure we decided to consider title of text as a key component in its perception. The premise of this paper, then, is that title placed in a 'strong position' in text significantly determines the strategy of text quantification. As a result, text quantification based on title leads the reader to objective senses of text, in other words, to its concept [4].

\section{Research Methods}

The research was carried out with the help of such methods as linguistic analysis, contextual analysis, and method of quantification. Title and body of text are viewed by us as two interrelated quanta (Q1 and Q2 respectively) connected to each other with the help of prospective and retrospective relations [5]. Q1 in accordance with its nature is much more ambiguous in comparison to Q2 and at the very beginning of perception has multiple interpretations. Moreover, Q1 evokes in the reader's memory experienced concepts that are called 'preconceptions'. It is well known already that preconceptions can influence how the world is perceived. Thus, it is possible to sum up, then, that text perception is closely connected with title of text. The given connection is possible to illustrate due to the perceptive analysis called Key Words Conception worked out by A.S. Shtern [6]. The main point of this analysis is that it defines in text language units or key words and phrases that can be helpful in its comprehension. In our case, the given method of analysis is useful to investigate title's nature as a quantum. 


\section{Analysis Results}

Taking into consideration all ideas and facts of the above discussion we may certainly declare that Q1 irradiates relevant linguistic and extra-linguistic information in the reader's mind and defines the text quantification process.

The tendency of Q1 for irradiation appears to be implemented in 4 ways that considered in the paper as main ones on the bases of the carried out survey. These ways are interdependent and work in text simultaneously. Generally, they can be divided into two levels - semantic and cognitive. Semantic level is comprised of distant repetition and paraphrasal repetition. Two other ways named in the article as connotative repetition (as it is based on connotative meaning) and intertextual repetition (based on intertextuality) belong to cognitive level and are closely connected with the reader's associations.

The evidences for the above-mentioned ideas about quantal nature of text perception can be taken from Kate Chopin's story 'A Pair of Silk Stockings' vividly illustrating first three ways of quantal connection between title and body of the text.

The story's main character is Mrs. Sommers, a wife and mother. Her family is very poor, and she is trying to pick up a few items of clothing for her children. On this particular day, she is tired and worn out as she goes about her errands. She is an expert at finding bargains and saving money, always looking for a good sale, but she finds a pair of silk stockings that she desires for herself. They feel nice against her skin, and the store has several in her size and in various colors. She buys them and immediately puts them on. Instead of continuing with her errands and heading towards the bargain bins as she normally does, Mrs. Sommers gets fitted for gloves, something she has not done for some time. After getting gloves, she is hungry, and treats herself to lunch at a nearby restaurant. Later she goes to the theatre, sitting among the elegantly dressed women and men crowding the theatre. Each time she does something for herself, she becomes more comfortable with herself. Consequently, she dreads going home more and more with each activity. The story ends with Mrs. Sommers sitting in a cable car, wishing that it would continue traveling forever.

It is necessary to clarify here, that under connotative repetition we understand repetition of words, phrases, utterances possessing the same connotation as title of text. Connotation is defined as something extra than just a word's conceptual sense. What exactly is connoted is 'debatable and dependent on a number of cultural variables' [7]. In many respects connotation offers us a greater insight into social attitudes than does conceptual meaning. Thus, in the given story the title 'A Pair of Silk Stockings' has rather positive connotation that is associated with wealth, money, richness, well-being, beauty, luxury, carelessness, desires, and so on and so forth.

Our review of the story perception based on the notion of quantum is illustrated below (see Table 1)

Table 1: Quantal relation between title and body of the story 'A Pair of Silk Stockings' written by K.Chopin.

\begin{tabular}{|l|l|}
\hline \multicolumn{1}{|c|}{ Type of repetition } & \multicolumn{1}{c|}{ Examples from the story } \\
\hline Distant repetition & $\begin{array}{l}\text { New stockings - two pairs apiece - and what darning that would save for a while! ...her hand had } \\
\text { encountered something very soothing, very pleasant to touch...her hand lay upon a pile of silk stockings; } \\
\text {...she changed her cotton stockings for the new silk ones which she had just bought; How good was the } \\
\text { touch of the raw silk to her flesh! Her stockings ... had worked marvels in her bearing - had given her a } \\
\text { feeling of assurance.... }\end{array}$ \\
\hline Paraphrasal repetition & $\begin{array}{l}\text { She went on feeling the soft, sheeny luxurious things...; to feel them glide serpent-like through her fingers; } \\
\text { What a small parcel it was! It seemed lost in the depths of her shabby old shopping bag. }\end{array}$ \\
\hline Connotative repetition & $\begin{array}{l}\text { Her foot and ankle looked very pretty; she wanted excellent and stylish fit; pretty, pleasant young creature; as } \\
\text { before a princess of royal blood; it was like a dream ended; brilliantly dressed women. }\end{array}$ \\
\hline
\end{tabular}

Connotative repetitions are mostly used in the part of the story where Mrs. Sommers is depicted in her new silk stockings. Once she put those silk stockings on, she received a small taste of the good life. Her attitude to world changed and she began to see everything in bright colors.

However, her happiness and carelessness did not last long. At the end of the day Mrs. Sommers understood what reality she belonged to: A man with keen eyes...seemed to like the study of her small, pale face. It puzzled him to decipher what he saw there... a poignant wish, a powerful longing that the cable car would never stop anywhere, but go on and on with her forever' [8, p.33].

In the illustrated passage the author uses oxymoron (poignant wish) to express the character's inner state full of contradiction between her wishes and future reality that was presented in the story with the help of similar 'the future like some dim, gaunt monster' [8, p.30]. Moreover, from the first point of view all desires of Mrs. Sommers were wrapped with 
positive connotation and were presented in the text by such lexis as 'wish, desire, she wanted, her craving'. But the last wish 'temptation' the meaning of which is defined in Macmillan English Dictionary as 'a strong feeling of wanting to have or to do something especially something that is bad for you'. Thus, at the end of the story the reader begins to see that Mrs. Soomers showed her weakness and forgot about her responsibilities. The word 'temptation' as a quantum is respectively connected with the adjective used earlier in the story to describe silk stockings 'serpent-like'. The given quantum evokes in the reader's mind extra-linguistic knowledge: snakes in Western culture are a symbol of sinfulness, deceit, and just general evil. The reason for this probably goes back at least to the story of Adam and Eve. In that, the serpent lures Eve into sin with his deceit. So the Judeo-Christian tradition starts with a snake causing the first sin to happen. Taking into account all the information from the story and personal experience, analyzing and synthesizing it, considering prospective and retrospective relations between Q1 and Q2 the reader is directed to conclude that luxury in wide meaning can make person forget his responsibilities. The examination of the story and its quanta helps us explore the theme that reflects the role of women in society. In 'A Pair of Silk Stockings' K. Chopin portrays the quite struggle of a woman searching for a balance between family life and personal satisfaction. The story's ambiguous ending suggests that the struggle is one that continuous to be encountered by women.

The adequate interpretation of text, as it was mentioned above, results in qualitative translation, this is absolutely true when we translate titles of literary works.

According to their nature titles perform not only informative function, but also serve as text structures that attract readers' attention, evoke interest. In addition, titles of texts belonging to belles-letters style are characterized by ambiguity, the meaning of which can only be deciphered after reading the text.

As the aim of this article is not to consider and analyze the translation of the abovementioned story, but to bring to light the role played by title in text interpretation and translation, we decided to present only the analysis of translation of the title.

During the research two ways to translate the title A Pair of Silk Stockings were found out, they are Пара шелковых чулок [9] and Шелковые чулки. Taking into consideration findings from the analysis made it is viewed important to point out that the later translation is more successful and it can be explained by two reasons. Firstly, the title Шелковые чулки demonstrates such a translational technique known in translation study as generalization that is when a precise piece of information presented in a general way. This way of rendering the title in question is more appropriate as it fully conveys the author's intention to show women's search for a balance between family life and personal satisfaction. The generalization of the information presented in the source text's title can be considered as qualitative shift that concerns the scope of the semantic fields of the source and target texts' titles. In the given case the translation Шелковые чулки can be named as minor explication of the source text information. Thus, the generalization of the source title itself points out the fact that describing one woman's situation the author implies that such a situation is a common knowledge among most women. Thus, the later Russian translation itself helps Russian readers understand the writer's intention.

Secondly, from the aesthetical point and one of the requirements of title creation that is titles must be short, the translation Шелковые чулки is much more acceptable as this title sounds more natural for Russian-speaking readers.

The idea to present title as a quantum evoking readers' potential to successfully decode writers' intentions in stories or novels can be also supported by our analysis of Jack London's short story To Build a Fire [10]. In this text's analysis only lexical (build a fire, fire, make a fire, fire-provider) and synonymous (flame, flamed) distant repetition of lexical units forming the title was taken into consideration. The meaning of these lexical units was deciphered from the context they are used in. Along the story lexical units included into the title were repeated totally 26 times in such contexts and order as a fire would be going, and a hot supper would be ready; to seek shelter somewhere and build a fire; he would be forced to stop and build a fire; he had forgotten to build a fire; proceeded to make a fire; he soon had a roaring fire; it (dog) was for its own sake that it yearned back toward the fire; the young flame; he fed the young flame; as the flame grew stronger; in his first attempt to build a fire; to build a fire he had been forced to remove his mittens; fire was a success; there was the fire, snapping and crackling and promising life with every dancing flame; the trail-mate could have built the fire; it was up to him to build a fire over again; it(dog) looked at him as the fire-provider, and the fire was slow in coming; he cherished the flame carefully; the fire-provider had failed; there were no sign of a fire to be made; never in the dog's experience had it known a man to sit like that in the snow and make no fire; it (dog) turned and trotted up the trail ... where there were the other food-providers and fire-providers. Underlined lexical units above have vital information assisting to understand the plot and idea of the story that is a human is a fragile creature that makes a fatal mistake because of his greed to make a fortune by digging gold in Alaska. Sometimes people get blind or they do not want to see harsh phenomena of reality in pursuit of gold, money and so on. Such a conclusion is possible to draw due to 
analyzing the meaning the word FIRE obtains while the whole story unfolds. At the end of the exposition FIRE accepts the meaning of LIFE.

\section{Conclusion}

In conclusion, in this discussion we attempt to examine in greater depth the notion that title plays a significant role in shaping a strategy of text quantification that is understood as natural process and a distinctive feature of text perception. The adequate text interpretation results not only in understanding writers' ideas and intentions but facilitates translation of literary texts. The approach suggested above can fully be used in text analysis practice and in the course of training future specialists intending to deal with works of literature. The main idea in using the suggested approach is to teach students to carry out a pre-reading analysis of the title. The given analysis is understood as assembling knowledge, associations connected to the title as a quantum on the basis of which to work out the text perception technique when the reader while reading a text takes mostly into consideration all text's linguistic and extra-linguistic features directly or indirectly having bonds with text title and consequently helping to decode the dominant intention of the author.

It is worth mentioning here as well that the quantitative approach based on title to text interpretation is limited by its nature as some quanta found in the text are cognitive that means the more erudite a translator is the more successful he/she is in analyzing texts.

\section{References}

Arnold, V. I. (1990). Modern English Stylistics. Moscow.

Flanagan, J.R. \& Lederman, S.J. (2001). Neurobiology: Feeling bumps and holes. News and Views. Nature.

Gibson, J. J. (1987). The Ecological approach to Visual Perception. Lawrence Erlbaum Associates.

Брудный А.А. (1975). Подтекст и элементы внетекстовых знаковых структур, Вопросы филологии 10, 34-42.

Гальперин И.Р. (1990). Текст как объект лингвистического исследования. Москва, Просвещение.

Штерн А.С. (1981). Влияние лингвистических факторов на восприятие речи. Дисс. Ленинград.

Finch G. (2005). Key Concepts in Language and Linguistics, $2^{\text {nd }}$ ed. Palgrave Macmillan.

Chopin K. (2005). A Pair of Silk Stockings. Ed. Paul Negri. NY: Dover Publications, Inc.

Миловидов А. Пара шелковых чулок http://www.proza.ru/2013/10/20/2140

London J. (2002) Great American Short Stories, Ed. Paul Negri. NY: Dover Publications, Inc. 